
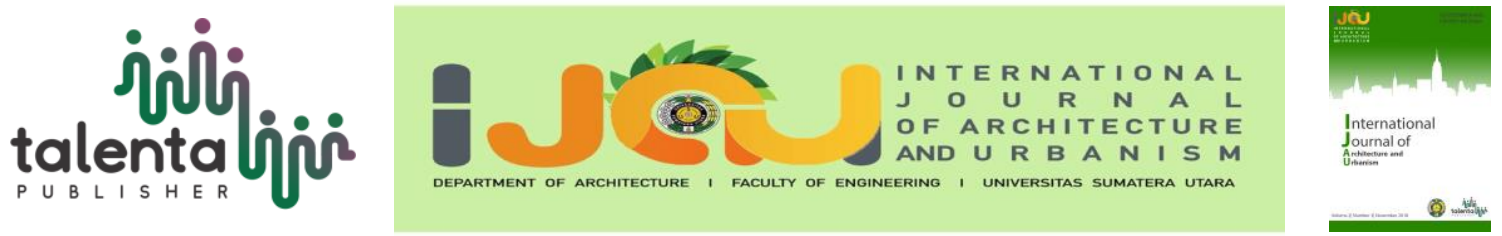

\title{
Polonia Apartment (Green Architecture)
}

\author{
Rajaian Edwin F. Sinambela ${ }^{*}$, Nelson M. Siahaan ${ }^{1}$ \\ ${ }^{1}$ Architecture Department, Faculty of Engineering, Universitas Sumatera Utara, Medan, Indonesia
}

\begin{abstract}
Medan City, Indonesia's third largest city with a strategic position as the main gateway of Indonesia in the western region, must prepare itself to develop in facing variousopportunities and challenges as a metropolitan city. Polonia's ex-terminal complex post-relocation Polonia Airport is a region with the high potential to become a strategic trading center in Medan. Taking into consideration the availability of the existing area, the concept of vertical-shelter construction is chosen that can be used as a trading place, office or second residence is known as an apartment. The apartment can be defined as a building consisting of several residential units arranged in stages, and has the same space and facilities, to overcome the problem of density of occupancy rate and limited land in urban areas. Therefore, the concept of "Green Architecture" is considered appropriate to address the environmental issues. Where the concept of green architecture (Green Architecture) is an approach to the building that can minimize the various harmful effects on human health and the environment.
\end{abstract}

Keyword: Apartment, green architecture, Medan, Polonia

\section{Introduction}

Medan City, the capital of the province of North Sumatra, is Indonesia's third largest city, with a strategic position as the main gateway of Indonesia in the western region; the city of Medan must be prepared to anticipate various opportunities and challenges as a metropolitan city. In line with this, the vision of the city of Medan to become a modern, civil and religious metropolis should continue to be developed in all development activities. Medan Polonia Subdistrict is an area which is $\pm 3.1 \mathrm{~km}$ from the center of Medan and is the airport area of Polonia and settlement. The central office, shopping, convention, recreation and entertainment (Central Business District) have also been built to become a vibrant and exciting new center of the national and regional level. In this area will also be developed office area of Provincial Government and City Government to reduce the flow of movement towards Central City Area and at the same time facilitate access of the population to get service in one area [1]. Also, the former area of Polonia airport is also the lungs of the city so that the field has great potential to

\footnotetext{
*Corresponding author at Department of Architecture, Faculty of Engineering, Universitas Sumatera Utara, Jalan Perpustakaan, Gedung J07, Medan, 20155, Indonesia

E-mail address: rajaiansinambela@gmail.com
} 
be developed into ecocity. Polonia's ex-terminal complex post-relocation Polonia Airport is a region with the high potential to become a strategic trading center in Medan. The apartment can be defined as a building consisting of several residential units arranged in stages, and has the same space and facilities, to overcome the problem of density of occupancy rate and limited land in urban areas. Where the apartment is divided into two based on the ownership system of rental apartments and apartment purchase [2].

Increasing the design of multi-level residential needs to consider the principle of sustainability through energy conservation in the achievement of thermal comfort, especially in humid tropics. Vegetation structuring can cool buildings and reduce cooling needs to create a microclimate that provides thermal comfort for residents. Multi-story residential lots have a large facade larger than the width of the site so it is potential to serve as an extension of green areas that can no longer be supported by the availability of land horizontally. One way to grow plants in sufficient quantities, although the space is very limited, is the concept of a vertical garden or Vertical Garden. Vertical Garden is an upright park concept, i.e., plants and other garden elements arranged in such a way in an upright field. With this concept, space can be much larger than conventional parks, even the number of plants that can be planted can be several folds so that it can increase the green space significantly [3].

With the making of Subdistrict Polonia as Central Bussiness District (CBD), it will increase the potential migration of residents from a region for the interests of political, social, economic, industrial, business and so forth. For that, it takes an effort to provide public facilities, one of which is residential that can accommodate some residents who moved to the region of Medan Polonia. Taking into consideration the availability of the existing area, the concept of verticalshelter construction is chosen that can be used as a trading place, office or second residence is known as an apartment. Therefore, the concept of "Green Architecture" is considered appropriate to address environmental issues. Where the concept of green architecture (Green Architecture) is an approach to the building that can minimize various harmful effects on human health and the environment. The green architecture includes more than just a human shelter building with all its functions [4].

\section{Literature Review}

\subsection{Elaboration Theme}

According to KBBI, Green Understanding is Green is part of the color spectrum that in the world of architecture is interpreted with cool, refreshing, decent with lam, and associated with plants. According to the World Health Organization (WHO), 30\% of buildings in the world experience indoor air quality problems. For that emerged the concept of green architecture is an architectural planning approach that tries to minimize the various harmful effects on human health and the environment. The concept of green architecture has several benefits such as 
building more durable, energy saving; building maintenance is more minimal, more comfortable inhabited, and healthier for residents. The concept of green architecture contributes to environmental problems, especially global warming. Moreover, the building is the largest producer of more than $30 \%$ of global emissions of carbon dioxide as one of the causes of global warming.

Designing an apartment with the goal of creating a comfortable vertical dwelling for the user. The concept of 'green' can also be applied to the reduction of energy use (e.g., electrical energy), low energy house and zero energy building by maximizing the building cover (building envelope). The use of renewable energy such as solar energy, water, biomass, and waste processing into energy is also worth considering, so it is worthy of being raised as the theme. The apartment is a residence (consisting of a sitting room, bedroom, bathroom, kitchen, etc.) located on one floor of a multi-story building; flat house; homeshare. Multilevel buildings divided into several dwellings.

Polonia comes from the Latin word meaning Polish. Baron Michalsky is a Polish particle entrepreneur who gets a land concession (tobacco plantation) in North Sumatra and names the land according to his homeland of Poland. Polonia is one of 21 sub-districts in Medan City, North Sumatra, Indonesia. Medan Polonia Sub-district borders Medan New to the west, Medan Maimun in the east, Medan Johor in the south, and Medan Petisah in the north [5].

This comparative study aims to obtain useful information to deal with the problems encountered in the design. Similar projects taken as comparative studies are Taman Anggrek Residence Apartments (Figure 1).

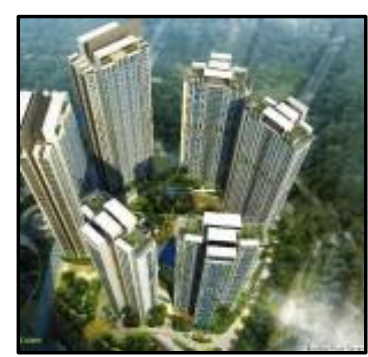

Figure 1. Taman Anggrek Residence Apartment

(Source:https://www.google.com/search?q=taman+anggrek+residence\&source)

The location of Taman Anggrek Residences is right next to Taman Anggrek Mall of West Jakarta, which is also very close to Central Park Mall. And also with famous universities like UNTAR and TrisaktiHarapan Kita Hospital and Dharmais Cancer Hospital are also within this TA Residence radius (Figure 2). 


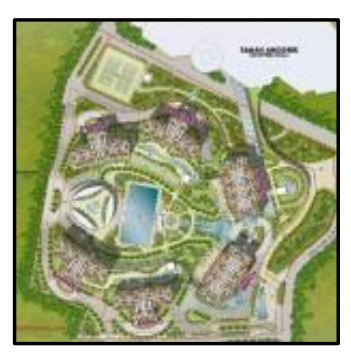

Figure 2. Floor Plan The Suite of TA Residence

(Source: https://investproperti.com/taman-anggrek-residences-apartemen-terbaru-di-jakartabarat/taman-anggrek-residences-site-plan/)

The building taken as a comparative case study of a similar theme is One East Apartment Surabaya. One East Residences Apartment carries the concept of a green building built on a land area of 5,000 square meters. The location of this building is the former office of RCTI bureau of East Java and Office of the operator Fren.

Application of the concept of green is very visible, one of which is when drilling for the manufacture of foundations that use special equipment, so as not to disturb the surrounding residents. To enhance the comfort of its residents, One East Residence is also equipped with various premium facilities, ranging from Rooftop Sky Infinite Pool \& Sky Lounge resort concept, Private Cinema, Multi-Function Hall, Modern Gym, and Kids Adventure Club to White-Gloves Services. With this service, residents get the privilege of luxury car shuttle service to the airport or other destinations, ticket/hotel reservation, to room-service and housekeeping.

Located in the elite and strategic area of Jalan Raya Kertajaya Indah Number 79 and close to the Middle-East Ring Road (MERR), One East Residence is surrounded by facilities ranging from well-known private universities, international hospitals, shopping centers, and business centers. With luxury and strategic location, the One East Residence apartment project also promises a very lucrative return on investment or can be rented with high rental value (Figure 3).

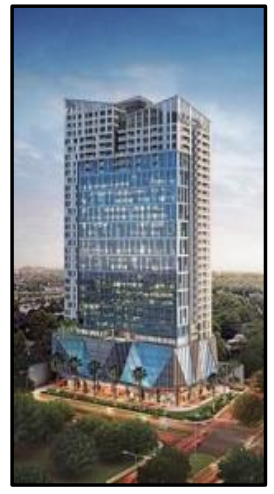

Figure 3. One East Apartment

(Source: http://www.agungsedayu.com/?commercial_site=taman-anggrek-residences)

He explained the units of The Royal Suites is intended for premium consumers because of its specifications using the material with the best quality. Like, marble floors for the living room 
and bedroom package. Then, kitchen cabinet, wardrobe in the main room, and AC split ducting. This continued Budi, who later distinguishes with some luxury apartments in Surabaya.

Regarding the size of the room, The Royal Suite still fits the premium class standard. Two rooms of size 80 square meters, while three rooms measuring 100 square meters. One East Residence offers several types of occupancy, ranging from one bedroom type, two bedrooms, three bedrooms. Also, as a premium-class residential, One East also presents a sky-sky concept unit. The concept of an apartment with soaking facilities placed on the apartment balcony is located on the top floor. With this concept, residents can freely enjoy the city view while bathing (Figure 4).

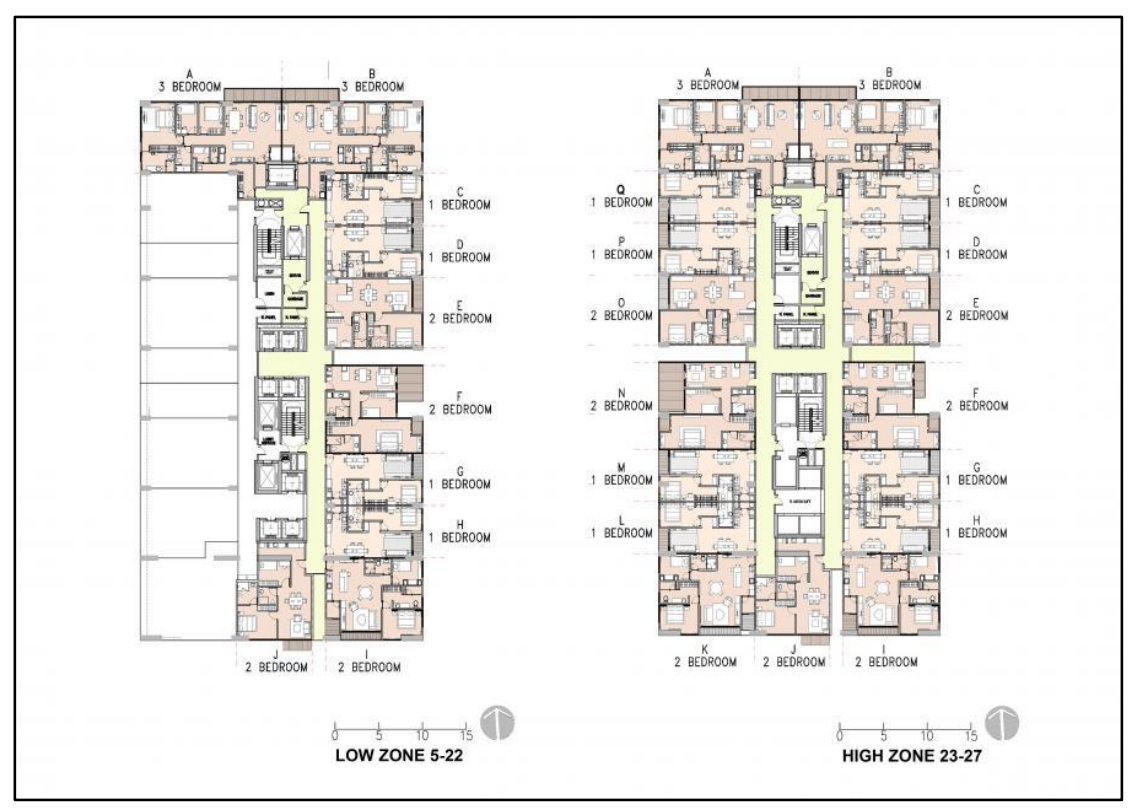

Figure 4. One East Apartment Details

(Source:https://www.urbanindo.com/komplek-perumahan/596-taman-anggrek-residence)

\section{Methodology}

The design process of Polonia Apartment started with literature study, field survey on design location, user, and action observation and continued with site analysis and design concept appointment, there are also case study to research similar project design case. The approach of design concept used is the thematic approach where design theme used is a theme of green architecture and approach to tread.

Field survey conducted at the location of the design with the object of research is the site condition and the surrounding environment. The location of observation is done in two locations, namely: Ex Polonia Airport. Object observation is the population around and observed is the behavior and activities of the surrounding population. 


\section{Result and Discussion}

The project location is located in the ex-Polonia Airport area which in RUTRK will be developed into a central business district (CBD Polonia) and a pilot green area in Medan City. The site potential such as: first, The site is located in the core of the city and is the former Polonia Airport which is planned to be developed into CBD and RTH areas. Second, the value of the land on the site design is very high and the land around the site of the middle and upper housing areas. The site issues such as, first, the designated land is an elite residential area that requires special quiet in designing the Convention Hall. Second, the location is directly adjacent to the Air Force Soewondo Air Force (Figure 5). The site solution such as, first, at the design of the Convention Hall, should pay attention to the acoustics of the outer and inner space so as not to disturb the peace of the local population. Second, the height of the building no more than four floors.

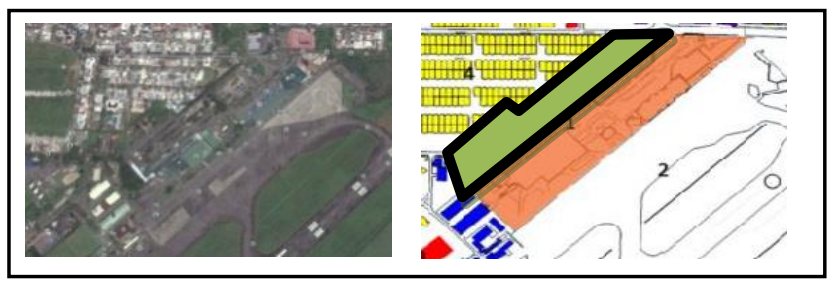

Figure 5. Site Location

The task of the designer, in this case, is to make a permanent shelter and temporary living which can be used as a solution to the narrow land use to meet the needs of a human dwelling. The Polonia Apartments are in a very potential location to be developed into a metropolitan area with a site location that is very close to the city center and is also a development project. The existence of this policy makes the Polonia Apartment a facility that must be realized in the area. After performing the analysis stage, it can be concluded that: first, the Polonia Apartments will be designed with a classification of three different types of occupancy: studio, deluxe and suites with four floors. Second, Polonia Apartment features a well-designed green architecture theme. Third, Polonia Apartments are designed on sites that contribute positively to the site in the same area so that in the future the intensity of activity in Polonia Apartments will increase.

The Polonia Apartments are designed as an iconic building for the city of Medan with a former Polonia airport-oriented look. By taking the form element site, then the formation of the Polonia apartment in the form of zigzag. And by analyzing the typology of an apartment, then this mass formation manifests itself. This building will stand out from the surrounding buildings. The effect will make the occupants of the apartment feel entering a different area. The design site with an area of $\pm 27,822 \mathrm{~m}^{2}$ is located in Polonia Ecocity integrated area bordering with housing, meeting hall, parking building, business hotel, and shopping mall. Site divided into several zoning, that is mass of main building with $\mathrm{KDB} 50 \% \pm 9,307 \mathrm{~m}^{2}$ and green open space $40 \%$ from land or $\pm 7,416 \mathrm{~m}^{2}$ (Figure 6). 


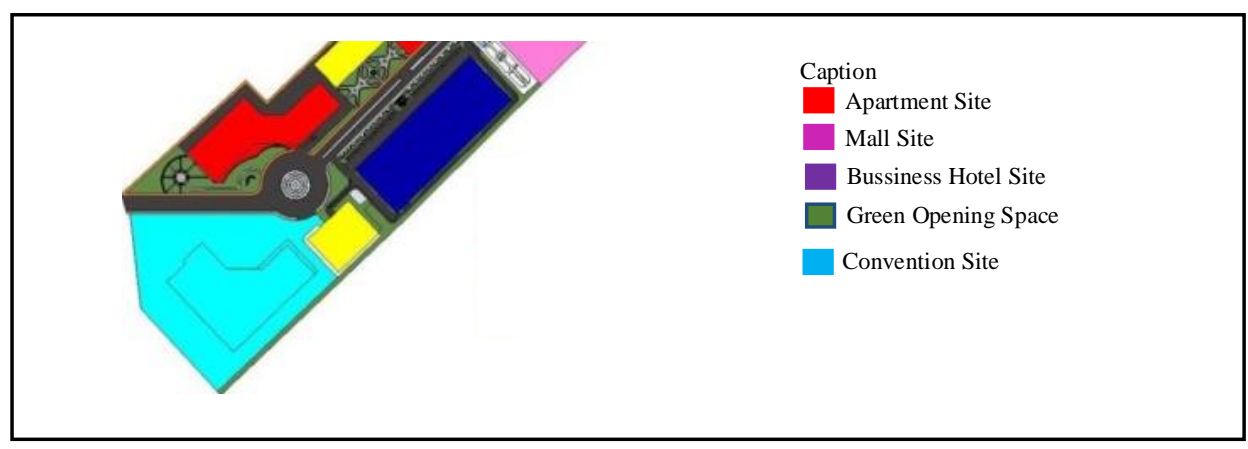

Figure 6. Concept Site

Outside spatial arrangement of site-oriented site processing around the main mass which is functioned as the park, playground of early childhood, and also parking building. For parking building specially reserved for apartment user. This is because to maintain the privacy and the parking needs of an apartment that must serve certain functions. In the Entrance section, there are drop off areas and fountain (Figure 7). The management of the landscape implements a bioswale system to deal with stagnant waterlogging that is capable of causing flooding. Through this system, water puddles can be absorbed through the formation of basins on land combined with the biosphere system.

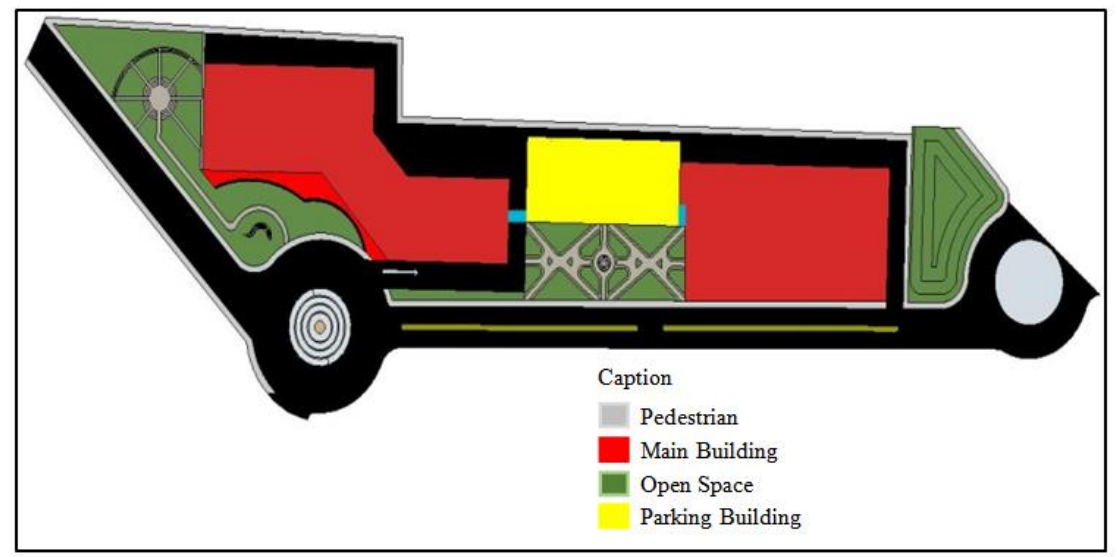

Figure 7.Outdoor Spatial Planning

The concept of the building period uses a rectangular base shape which is then placed on the footprint and adapts the shape and orientation of the site. In the first (1) period carried out addition or addition of the period to form a building that its formation combines two rectangles. While in the second (second) subtraction or reduction of a form (Figure 8). Space zoning is divided based on the needs analysis and the amount of space (Figure 9).

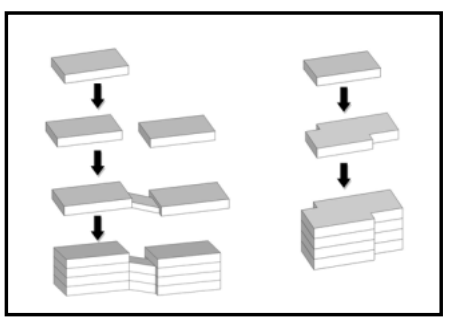

Figure 8. Form Shape 


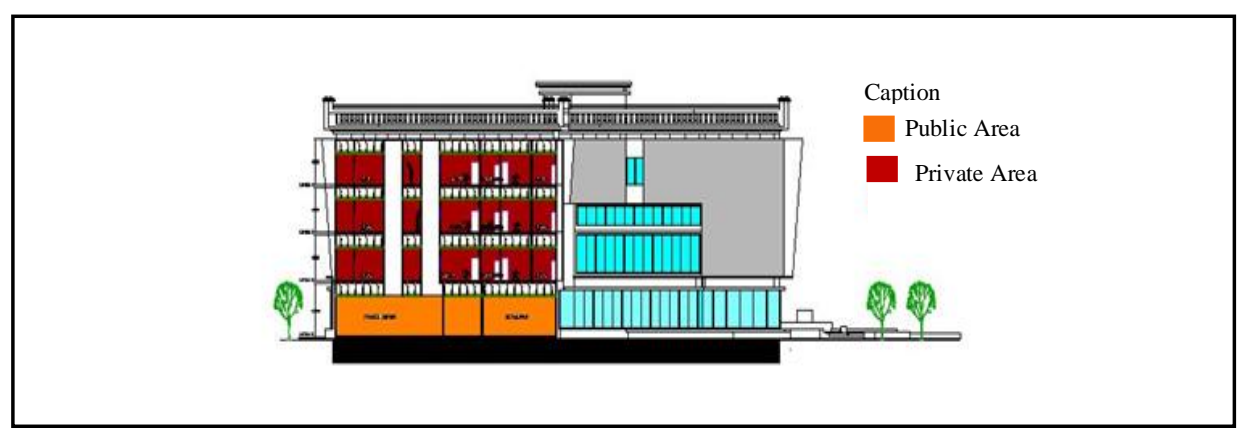

Figure 9. Space Zoning

Site circulation starts from the main entrance (main entry lane) directly to the drop off area. The distance between the main entrance and the drop off area is not too far away. This is to facilitate the visitors can immediately find the main building of the apartment. For the entrance to the apartment building provided two-lane entrance where the entrance is located at the front of the building. As for the service line, there are two pieces of lanes located at the rear of the building. Planning a parking area is provided a parking lot capable of loading \pm 100 cars and \pm 200 motorcycles. This parking building itself has retail that provides daily necessities that can meet the needs of the apartment users. Green planning is designed with Green Architecture concept. Saving energy on buildings, polluting the roads, and adding a comfortable, safe, and shady atmosphere are the main goals of this green design (Figure 10).

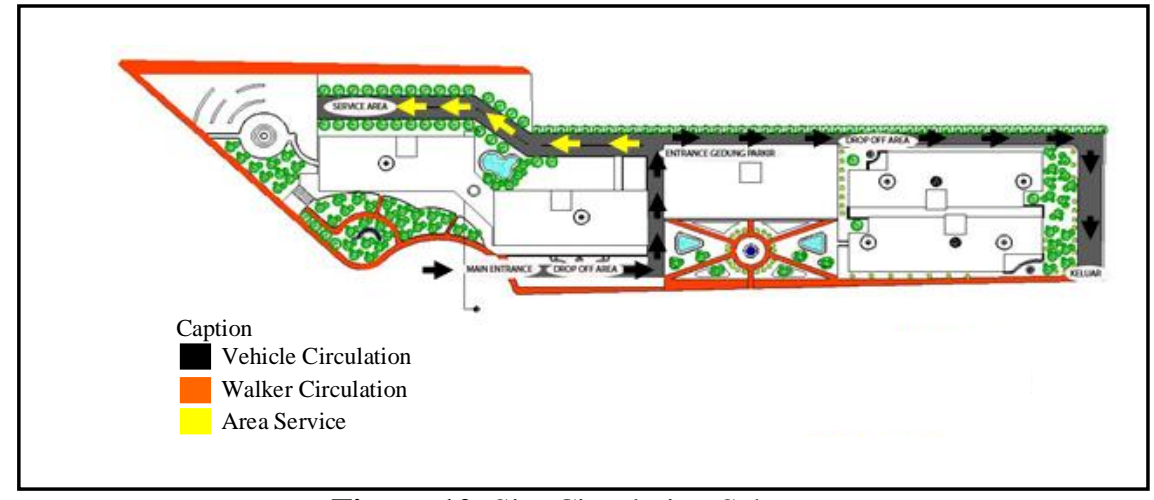

Figure 10. Site Circulation Scheme Source: author 2018

\section{Conclusion}

In the design of apartment facilities, there are several things to note is the location of the site and the needs of potential users. The design site of this apartment is located in the former Polonia airport which is located near the Soewondo Air Force base so that the mass and landscape formation needs to be processed to reduce the noise from the Soewondo airstrip. Location of this design is also close to the settlement of citizens and is one of the areas that will be developed into a central business area so that the designed facilities should consider both potentials. 
The concept of designing this apartment is to provide permanent and temporary shelter facilities for users to support activities and activities. Because basically, a good building is a building that can provide a sense of security and comfort for its users. For that, the theme applied is Green Architecture applied to the apartment building technique. With large space and user capacity, designed parking facilities must also be in line with the needs of its users. Therefore, parking is provided that can accommodate the needs of parking lots for the users and visitors of the apartment.

\section{Acknowledgment}

This research is part of the requirement to obtain a bachelor's degree in Architecture Department, Universitas Sumatera Utara.

\section{REFERENCES}

[1] Melissa Sharon Riyono, Apartemen di Daerah Istimewa Yogyakarta. Yogyakarta: Program Studi Arsitektur, Fakultas Teknik, Universitas Atma Jaya, 2014.

[2] Laloan dkk, Apartemen di Manado "Penerapan Konsep Vertical Garden". Manado: Program Studi S1 Arsitektur UNSRAT, 2015.

[3] Andri Rizky Nurkamdani, Rumah Container Bertingkat dengan Pendekatan Metabolist. Surakarta: Program Studi Arsitektur, Fakultas Teknik, Universitas Sebelas Maret, 2010.

[4] Cynthia Mutiara Pasaribu, "Kajian Isu Pemekaran Kota Medan: Tinjauan Berdasarkan Kondisi Ketimpangan Wilayah," Jurnal Wilayah dan Lingkungan Vol.3, No.3 P-ISSN: 2338-1604, 2015.

[5] (2016, 16 Oktober) Wikipedia. [Online]. https://id.wikipedia.org/wiki/Medan,_Polonia. 